\title{
Penile and scrotal lymphedema associated with hidradenitis suppurativa: Case report and review of surgical options
}

\author{
Linfedema penoescrotal secundario a hidrosadenitis supurativa: a propósito de un caso, \\ revisión de las opciones quirúrgicas
}

\author{
Yvan D. Pacheco*, Orlando García-Duque and Javier Fernández-Palacios \\ Department of Plastic Surgery, Hospital Universitario de Gran Canaria Dr. Negrín, Las Palmas de Gran Canaria, Spain
}

\begin{abstract}
Lymphedema is the result of an alteration of the lymphatic drainage, and its most common worldwide cause is filariasis. In our practice usually is associated to neoplasic, inflammatory and granulomatous processes, radiotherapy, hydroelectrolytic disbalances, and idiopathic. It can affect any part of the body, including the penis and scrotum. The genital lymphedema is a rare presentation, it corresponds to $0.6 \%$ of lymphedema. However, causes serious functional, social and emotional limitations for the patient. Too often have pain, recurrent infections, sexual dysfunction, cosmetic deformity, sometimes it limits mobility and ambulation. Although there are several treatment options, both medical and surgical, it has not been found ideal for this disease. We present a 43 years old patient with penoscrotal lymphedema due to hidradenitis suppurativa, it limits his normal activity. The patient was referred to our center after unsuccessful medical treatment (doxycycline and clindamycin cycles). Surgical treatment consisted of total excision of the skin and subcutaneous tissue to Buck's fascia. Split thickness skin grafts were used to cover the defect. The result was satisfactory both functionally and aesthetically.
\end{abstract}

KEY WORDS: Lymphedema penoscrotal. Hidradenitis. Surgical treatment.

\section{Resumen}

El linfedema es producto de una alteración en el drenaje linfático, y su causa más frecuente en todo el mundo es la filariasis. En nuestro medio suele encontrarse asociada a procesos neoplásicos, inflamatorios, granulomatosos, secuelas por radioterapia, desequilibrios hidroelectrolíticos y procesos idiopáticos. Puede afectar a cualquier parte del cuerpo, incluyendo el pene y el escroto. El linfedema genital es una presentación infrecuente, que corresponde al $0.6 \%$ de los linfedemas. No obstante, causa graves limitaciones funcionales, sociales y emocionales para el paciente. Con mucha frecuencia se presentan dolor, infecciones recurrentes, disfunción sexual y deformidad estética, llegando incluso a limitar la movilidad y la deambulación. Aunque existen varias opciones de tratamiento, tanto médico como quirúrgico, no se ha encontrado el ideal para esta enfermedad. Presentamos el caso de un paciente de 43 años afecto de hidrosadenitis axilar e inguinal que padece linfedema penoescrotal grave que limita seriamente su actividad habitual. El paciente fue remitido a nuestro centro tras el fracaso del tratamiento con antibióticos (ciclos de doxiciclina y clindamicina). El tratamiento quirúrgico consistió en la resección de piel y tejido celular subcutáneo hasta fascia de Buck y cobertura con injertos de piel. El resultado final fue adecuado desde un punto de vista tanto funcional como estético.

PALABRAS CLAVE: Linfedema penoescrotal. Hidrosadenitis. Tratamiento quirúrgico.

\author{
Correspondence: \\ *Yvan Pacheco \\ Av. Escaleritas 64, piso 18-2 \\ C.P. 35011, Las Palmas de Gran Canaria, España \\ E-mail: pachecoplasticsurgery@ hotmail.com
}

Date of reception: 20-01-2017

Date of acceptance: 14-02-2018

DOI: $10.24875 / C I R U E . M 18000012$
Cir Cir. 2018;86:77-80

Contents available at PubMed www.cirugiaycirujanos.com 


\section{Introduction}

Hidradenitis suppurativa is a recurrent inflammatory disease of the apocrine glands that affects the axillae, the submammary groove, the groin area, the perineum and the intergluteal cleft. Its etiology is unknown, but immunohistochemistry studies suggest an immune cause mediated by interleukins and by tumor necrosis factor alpha'.

Hidradenitis affects $1 \%$ of the population, with an incidence of $6 / 100,000$ person-years ${ }^{1,2}$, with females being more affected, although the most serious forms occur in males $^{3}$, among which the development of penoscrotal lymphedema has been described ${ }^{4}$.

Penoscrotal lymphedema accounts for $0.6 \%$ of lymphedemas ${ }^{5}$ and its most frequent cause is obstruction of the lymph channels by the filarial parasite ${ }^{6}$; however, in our setting, this presentation is much less common, and it is mainly secondary to neoplastic, post-surgical, post-radiotherapy and granulomatous processes. Other less common causes include infiltration of exogenous substances, such as paraffin or silicone, and hidradenitis suppurativa ${ }^{6,7}$.

Regardless of the cause, histological findings are characteristic. There are dilations observed of the lymphatic capillaries surrounded by endothelium, called vesicles, which compress the epidermis. These lymphatic dilatations converge in the subcutaneous layers and form cisterns that are surrounded by muscle tissue, whose contraction favors the dilation of superficial vesicles ${ }^{8}$.

The treatment of penoscrotal lymphedema should be according to its etiology; when etiological treatment is not possible, it shall be surgical. Compressive and pressure therapy measures are impractical and uncomfortable.

The different surgical techniques are based on the resection of skin and subcutaneous cellular tissue plus coverage with skin flaps or grafts ${ }^{9}$. In cases of small lymphedemas, the Feins technique ${ }^{10}$ with genital skin preservation and only lymphedematous tissue extirpation can be used.

When lymphedema is more important, which occurs in most cases, coverage should take into account whether it involves the penis or the scrotum. For penile coverage, total skin grafts or a partial thick skin graft are preferred ${ }^{10}$. Flaps are unsatisfactory in the penis, both functionally and esthetically.

Several options have been described for scrotal coverage :

- Posterolateral scrotal advance flap (mildly compromised area in the lymphedema).

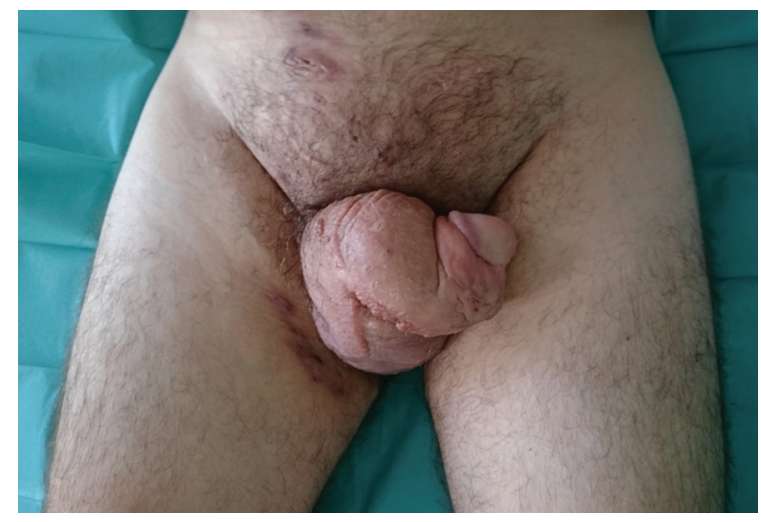

Figure 1. 43-year-old male with penoscrotal lymphedema of 9 months' evolution.

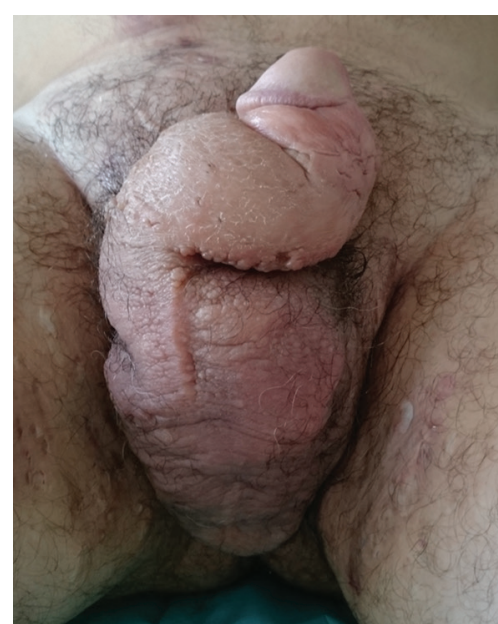

Figure 2. In the same patient, notice the acquired deformity, with great functional and esthetic compromise.

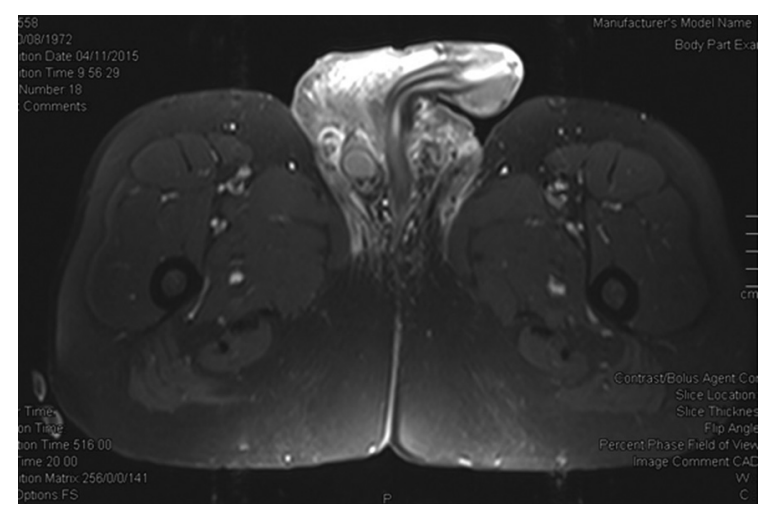

Figure 3. Contrast-enhanced MRI (axial section), where significant penial thickening is observed, which in some areas can reach $3 \mathrm{~cm}$ in diameter.

- Medial thigh flap.

- Free partial skin graft.

The decision on the technique for testicular coverage shall be made taking into account thermoregulation alteration in case of non-scrotal flaps and instability in case of grafts $^{7,9}$. 


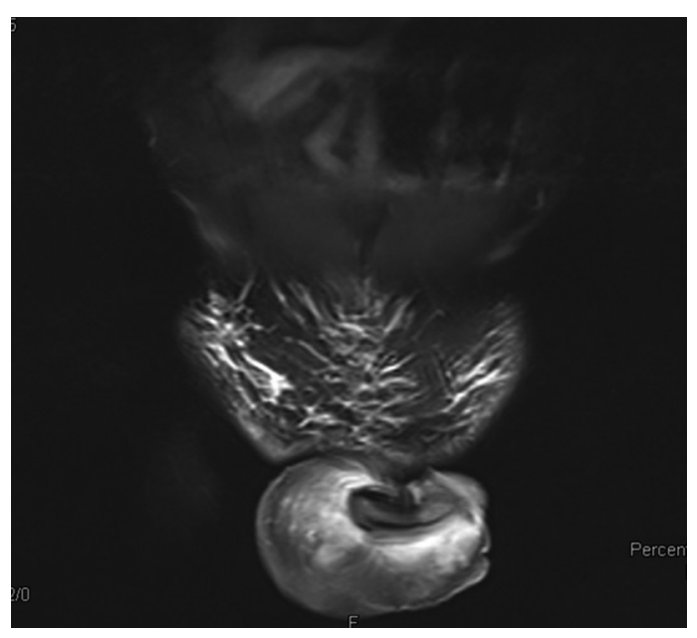

Figure 4. Contrast-enhanced MRI (coronal section). Notice the important 'penile curvature of the patient.

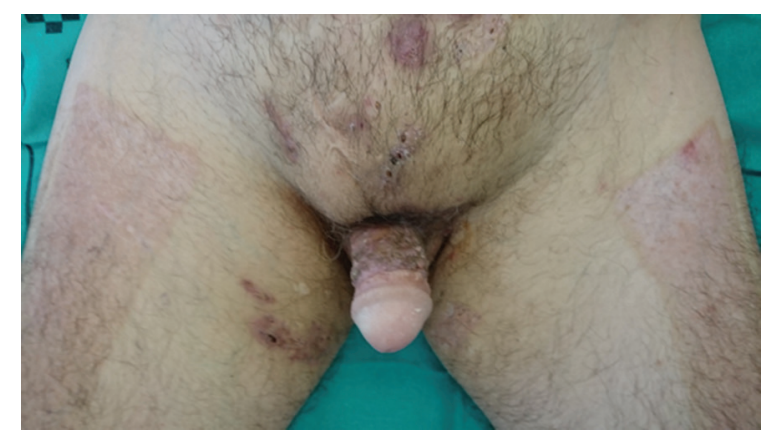

Figure 5. At 3 months post-surgery.

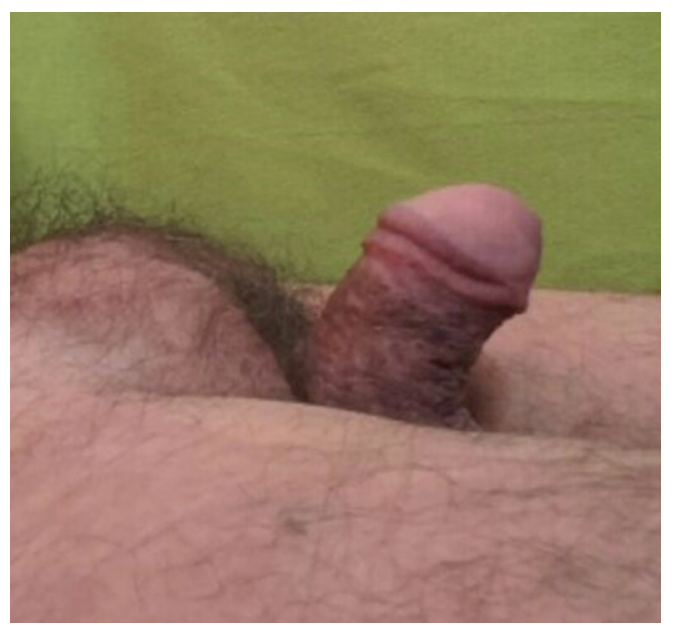

Figure 6. Stable skin coverage; no signs of edema relapse or penile curvature are observed.

\section{Clinical case}

We present the case of a 43-year-old man with a history of axillary hidradenitis that was operated a few years prior, and active inguinal hidradenitis, who was referred to our practice due to enlargement of the penis and scrotum starting a few months ago, associated with severe pain, functional and sexual impairment, and difficulty walking. He denied exogenous substances infiltration and travels abroad in recent months. Sexually transmitted diseases were ruled out. At his center of origin, he was treated with a cycle of doxycycline for 4 weeks and clindamycin for 2 weeks, without improvement of the condition, which is why he was referred to our center.

Examination revealed important lymphedema of the penis and scrotum, as well as old and active inguinal hidradenitis lesions (Figs. 1 and 2).

As complementary studies, a soft tissue MRI of was performed, which reported severe inflammatory-infectious involvement in the scrotum and penis, with microabscesses and cutaneous fistulas, and soft tissue thickening, which was as large as $5 \mathrm{~cm}$ in the scrotum and $2.9 \mathrm{~cm}$ in the penis (Figs. 3 and 4). Abdominopelvic ultrasound ruled out obstructive processes. Joint intervention with the urology department was decided.

Extensive debridement was carried out up to Buck's fascia in the penis and external spermatic fascia in the scrotum, with testicular fixation and delayed coverage. A sample was sent to pathological anatomy and microbiology.

Anatomical pathology results indicated skin with lymphangiectasias, skin fibrosis and formation of sinuses delimited by inflammatory tissue at different evolutionary stages, with abscess formation and reepithelialization, which were findings consistent with hidradenitis suppurativa. Culture of the purulent material revealed the presence of Prevotella bivia.

After wound granulation and evident clinical improvement of the patient, proceeding to penile coverage was decided by means of a total skin graft taken from the abdominal region, which was circumferentially placed to avoid the appearance of retractable bridles, while the scrotum was covered with a partial skin graft taken from the left thigh. On post-op assessments, the scrotum graft had taken perfectly, but not that of the penis. Definitive coverage of the penis was attained with a thick partial laminar skin graft taken from the right thigh and equally placed in the spiral form. The graft was completely taken, and the patient was discharged at 7 days. Three months later, the patient showed stability of the penile skin coverage, did not have any pain and had erections; there were no signs of edema recurrence or penile curvature (Figs. 5 and 6). At 6-month follow-up, the patient referred having started satisfactory sexual activity.

\section{Discussion}

The lymphatic drainage of the penis and the scrotum takes place through the superficial inguinal lymph 
nodes, and thus the diseases that affect the skin and annexes of the groin may present with penoscrotal lymphedema, as it is the case of hidradenitis.

The main cause of lymphedema in the world is filariasis ${ }^{6}$. In developed countries, it is mainly due to pelvic surgery or prior radiotherapy, and less frequently to chronic inflammatory processes, such as hidradenitis ${ }^{6,7}$. There are also primary forms that usually occur at puberty, whose etiology is poorly known and that usually have hypoplasia of the lymph channels associated ${ }^{11}$.

The diagnosis of penoscrotal lymphedema is clinical; imaging tests help rule out obstructive pelvic and abdominal processes, and in preoperative planning ${ }^{11}$.

In some cases, treatment can be etiological and medical, although in most of them, due to chronic involvement and irreversible damage to the skin and subcutaneous tissue, surgery is the choice ${ }^{9}$. Since hidradenitis has no etiological treatment, it is also a candidate for surgery.

Our patient had a history of nearly one year of evolution. At his center of origin, he was treated with several cycles of antibiotic therapy, without results being obtained. Over time, pain and deformity increase, which can even impact on gait.

The objectives of surgical treatment are to achieve acceptable esthetics and preserve functionality and fertility, as well as to prevent relapses ${ }^{9}$.

Treatment includes complete resection of skin and subcutaneous tissue of the penis and scrotum. Penile coverage with total or partial thick grafts is almost universally accepted, ${ }^{9}$ with circumferential placement being the best in this case in order to avoid retractable bridles. Scrotal coverage has several options ${ }^{10}$; the use of non-scrotal local flaps is known to likely cause infertility by altering testicular thermoregulation, and lamellar grafts can be more unstable and suscepti$b^{7} e^{7,9}$. Although scrotal flaps are the ideal option, they require indemnity of the scrotum posterolateral skin, which rarely occurs in genital hidradenitis ${ }^{9,10,12}$.

In our patient, the first total skin grafts in the penis were not successful; we believe because of the thickness of the donor area, while the thick partial grafts were very well taken. Thus, a highly satisfactory result was obtained, with great functional, esthetic and social improvement at 3- and 6-month assessments.

\section{Conclusions}

Penoscrotal lymphedema secondary to hidradenitis suppurativa is a rare problem that causes great functional, esthetic and social limitations in patients.
We believe it is important to report our experience in the management of this pathology and our results, for the sake of facilitating therapeutic decisions in hospital personnel familiarized with this condition.

We conclude that, in case of chronic penile lymphedema with significant functional impairment, surgical treatment based on radical resection of skin and subcutaneous tissue, with subsequent coverage with skin grafts, remains one of the best therapeutic options.

\section{Ethical responsibilities}

Protection of people and animals. The authors declare that no experiments have been conducted on humans or animals for this research.

Confidentiality of data. The authors declare to have followed the protocols of their work center on the publication of patient data.

Right to privacy and informed consent. The authors have obtained informed consent from the patients and/or subjects referred to in the article. This document is in possession of the corresponding author.

\section{Funding}

No subsidies have been received for this work.

\section{Conflict of interests}

There are no conflicts of interests.

\section{References}

1. Jemec GB. Clinical practice. Hidradenitis suppurativa. N Engl J Med. 2012;366:158-64

2. Jemec GB, Heidenheim M, Nielsen $\mathrm{NH}$. The prevalence of hidradenitis suppurativa and its potential precursor lesions. J Am Acad Dermatol. 1996;35:191-4.

3. Vazquez BG, Alikhan A, Weaver AL, et al. Incidence of hidradenitis suppurativa and associated factors: a population-based study of Olmsted County, Minnesota. J Invest Dermatol. 2013;133:97-103.

4. Recalde-Losada C, Rubio-Verdú R, Solesio Pilarte F, et al. Abordaje quirúrgico de la elefantiasis escrotal, a propósito de dos casos graves. Cir Plast Iberolatinoam. 2014;40:205-12.

5. Schook C, Kulungowski A, Greene A, et al. Male genital lymphedema: clinical features and management in 25 pediatric patients. J Pediatr Surg. 2014;49:1647-51.

6. Dandapat MC, Mohapatro SK, Patro SK. Elephantiasis of the penis and scrotum. A review of 350 cases. Am J Surg. 1985;149:686-90.

7. García-Tutor E. Tratamiento quirúrgico del linfedema peneano secundario a hidrosadenitis supurativa. Actas Urol Esp. 2005;29:519-22.

8. Chéliz G, Belinki J, Kogan D, et al. Linfedema crónico genital. Plástica reconstructiva. Rev Arg Urol. 2004;69:181-3.

9. McDougal WS. Lymphedema of the external genitalia. J Urol. 2003; 170:711-6.

10. Feins NR. A new surgical technique for lymphedema of the penis and scrotum. J Pediatr Surg. 1980;15:787.

11. Halperin TJ, Slavin SA, Olumi AF, et al. Surgical management of scrotal lymphedema using local flaps. Ann Plast Surg. 2007;59:67-72.

12. Malloy TR, Wein AJ, Gross P. Scrotal and penile lymphedema: surgical considerations and management. J Urol. 1983;130:263-5. 